\title{
Priority local criteria for choosing of building technology
}

\author{
Elena Zholobova, ${ }^{1, *}$ \\ ${ }^{1}$ Don State Technical University, 344022, Rostov-on-Don, Russia
}

\begin{abstract}
The article contains some suggestions on the formation of sets of local criteria for the selection of optimal building technologies. Tables of priority local criteria universal for all building technologies are provided. Interest of the construction participants in use of these criteria is proved. Application of priority local criteria will allow to exclude expenses of time for their analysis and to avoid mistakes at their choice and also to provide possibility of automation of the choice of optimum building technologies.
\end{abstract}

\section{Introduction}

In the course of centuries of development of building production and, especially, in recent decades, many technologies have been developed for the construction of buildings and structures. Depending on the conditions of application, the efficiency of building technologies can sharply change, going sometimes beyond the permissible values [1-6].

Unfortunately, this dependence does not allow taking into account most of the known methods for assessment of the effectiveness of building technologies [7-9], and the few of these methods that have such a possibility are not universal and can be used to assess of only certain types of technologies [10-14].

The relevance of this problem is demonstrated by inability of these methods to consider the different interests of the customer, contractor, designer and other representatives of investment complex.

Thus, complex assessment of efficiency of building technologies is rather difficult and responsible task, the correct solution of which depends on a set of not only permanent internal, but also changing in time external factors.

\section{Results of research}

During the research executed at the Don State Technical University, three internal and three external factors that can influence on the result of complex assessment of efficiency of any building technologies were revealed. At the same time, the internal, that is, the target factors were assigned:

\footnotetext{
* Corresponding author: Elena@rniiakh.ru
} 
- Availability of technology is the complex indicator that characterizes the possibility of using building technology and the moderation of associated costs,

- Quality of the equipment used is a set of advantages of the applied building equipment,

- Quality of building products is a set of properties of building products that determine its suitability to satisfy certain requirements according to its assignment.

Among the external, that is, limiting factors, were revealed:

- Inauthenticity of diagnostic information is a factor that causes an increase in the cost and labor intensity of building products due to the need to perform an additional number of unforeseen (unaccounted) works,

- Production factor is a factor that takes into account the risk of deterioration of working conditions,

- Operational factor is a factor that significantly reduces the reliability of construction products, in the case of deterioration of its operating conditions.

Each of these factors can be described a set of parameters, that is the indicators characterizing any property of factor which can be used as local criteria at complex assessment of competitiveness of construction technologies [15].

It is considered [16-19] that the formed set of the criteria for assessment of any decision (in our case of technological), must possess the following properties:

- Criteria must be definitely understood and measurable,

- Criteria must be irredundant to avoid duplication in the assessment of a decision,

- It is expedient to include in the set of criteria for assessment of the decision only criteria without which such evolution is impossible.

During the research, it is established that 20 parameters of internal and external factors can be used as local criteria for a complex assessment of any building technology. Using more criteria is inexpedient due to the limited psychological capabilities of the person to keep them in memory and analyze. Belonging to a particular factor and the entities of these parameters are shown in the Tables 1 and 2.

Table 1. Parameters of the internal factors influencing the complex assessment of the efficiency of building technologies

\begin{tabular}{|c|c|c|}
\hline $\begin{array}{l}\text { Internal } \\
\text { factors }\end{array}$ & $\begin{array}{l}\text { Parameters of internal } \\
\text { factors }\end{array}$ & Parameter entity \\
\hline \multirow{5}{*}{$\begin{array}{l}\text { Availability } \\
\text { of } \\
\text { technology }\end{array}$} & $\begin{array}{l}\text { Wastelessness of } \\
\text { technology }\end{array}$ & $\begin{array}{l}\text { Reflects the effectiveness of the technology in the amount } \\
\text { of building waste obtained in the production of works }\end{array}$ \\
\hline & $\begin{array}{l}\text { Dirt adherence of } \\
\text { common air }\end{array}$ & $\begin{array}{l}\text { The indicator of ecological compatibility of the technology } \\
\text { characterizing the danger of harmful emissions into the } \\
\text { atmosphere }\end{array}$ \\
\hline & Cost of works & $\begin{array}{l}\text { Monetary assessment of all expenses required for the } \\
\text { construction or repair of a building product unit }\end{array}$ \\
\hline & $\begin{array}{l}\text { Injury risk of } \\
\text { technology }\end{array}$ & $\begin{array}{l}\text { Considers the probability of injury to workers at violation } \\
\text { of the rules of safety measures }\end{array}$ \\
\hline & $\begin{array}{l}\text { Labour input of } \\
\text { process }\end{array}$ & $\begin{array}{l}\text { The mean value of time (in man-hour) spent by } 1 \text { worker } \\
\text { for the construction or repair of a building product unit }\end{array}$ \\
\hline \multirow{2}{*}{$\begin{array}{l}\text { Quality of } \\
\text { the used } \\
\text { equipment }\end{array}$} & $\begin{array}{l}\text { Fire danger of the } \\
\text { equipment }\end{array}$ & $\begin{array}{l}\text { Characterizes the ability of working equipment to cause a } \\
\text { fire, due to the ignition of materials or equipment }\end{array}$ \\
\hline & $\begin{array}{l}\text { Transportability of } \\
\text { the equipment }\end{array}$ & $\begin{array}{l}\text { Characterizes the adaptability of the equipment for } \\
\text { transportation and depends on its size, weight and form }\end{array}$ \\
\hline \multirow[b]{2}{*}{$\begin{array}{l}\text { Quality of } \\
\text { construction } \\
\text { products }\end{array}$} & $\begin{array}{l}\text { Durability of } \\
\text { building products }\end{array}$ & Calculating or residual service life of building products \\
\hline & $\begin{array}{l}\text { Maintainability of } \\
\text { building products }\end{array}$ & $\begin{array}{l}\text { The adaptability of building products for the prevention and } \\
\text { elimination of failures occurrence reasons, as well as the } \\
\text { elimination of their consequences, through repairs and } \\
\text { maintenance }\end{array}$ \\
\hline
\end{tabular}




\begin{tabular}{|l|l|l|}
\hline & $\begin{array}{l}\text { Aesthetics of } \\
\text { building products }\end{array}$ & $\begin{array}{l}\text { The ability of the construction surface to increase } \\
\text { architectural expressiveness of a building or other structure }\end{array}$ \\
\hline
\end{tabular}

Table 2. Parameters of the external factors influencing the complex assessment of the efficiency of building technologies

\begin{tabular}{|c|c|c|}
\hline $\begin{array}{l}\text { External } \\
\text { factors }\end{array}$ & Parameters of external factors & Parameter entity \\
\hline \multirow{2}{*}{$\begin{array}{l}\text { Unauthenticity } \\
\text { of diagnostic } \\
\text { information }\end{array}$} & $\begin{array}{l}\text { Possibility of identification of } \\
\text { unaccounted geological } \\
\text { anomalies in construction zone }\end{array}$ & $\begin{array}{l}\text { Considers the additional expenses for performing a } \\
\text { large volume of unexpected work connected with } \\
\text { the necessity to protect the construction object } \\
\text { from geological anomalies that are not included in } \\
\text { the project }\end{array}$ \\
\hline & $\begin{array}{l}\text { Possibility of identifying } \\
\text { unaccounted shortcomings in } \\
\text { the structure being repaired }\end{array}$ & $\begin{array}{l}\text { The same is connected with the necessity of } \\
\text { elimination of the internal defects and damages } \\
\text { not included in the project in the repaired } \\
\text { structure }\end{array}$ \\
\hline \multirow{5}{*}{$\begin{array}{l}\text { Production } \\
\text { factor }\end{array}$} & $\begin{array}{l}\text { Risk of interruptions in supply } \\
\text { with materials }\end{array}$ & $\begin{array}{l}\text { Considers the additional expenses arising from } \\
\text { forced breaks in work and reduced productivity } \\
\text { of labour due to the lack or shortage of materials } \\
\text { at the construction object }\end{array}$ \\
\hline & $\begin{array}{l}\text { Risk of interruptions in power } \\
\text { supply }\end{array}$ & $\begin{array}{l}\text { The same is due to the inability to use electrical } \\
\text { equipment and artificial lighting }\end{array}$ \\
\hline & Risk of windy weather & Same with a strong wind (more than $10 \mathrm{~m} / \mathrm{s}$ ) \\
\hline & Risk of rainy weather & The same is due to the frequent rains \\
\hline & Risk of winter work conditions & $\begin{array}{l}\text { The same is true when the temperature of the } \\
\text { atmospheric air drops below } 0^{\circ} \mathrm{C} \text {, snowfall and } \\
\text { icing of structures }\end{array}$ \\
\hline \multirow{3}{*}{$\begin{array}{l}\text { Exploitation } \\
\text { factor }\end{array}$} & $\begin{array}{l}\text { Risk of increasing the intensity } \\
\text { of the building products use }\end{array}$ & $\begin{array}{l}\text { Considers the expenses of elimination the } \\
\text { consequences caused by the increase in duration } \\
\text { or intensity of mechanical and other influences } \\
\text { during the exploitation of building products }\end{array}$ \\
\hline & $\begin{array}{l}\text { Risk of deformation of } \\
\text { supporting structures and } \\
\text { different type of the bases }\end{array}$ & $\begin{array}{l}\text { The same is caused by uneven deformation of the } \\
\text { supporting structures and various types of bases }\end{array}$ \\
\hline & $\begin{array}{l}\text { Risk of deterioration of heat and } \\
\text { moisture conditions of the } \\
\text { building products exploitation }\end{array}$ & $\begin{array}{l}\text { The same is caused by its excessive moistening, } \\
\text { cooling or heating }\end{array}$ \\
\hline
\end{tabular}

* The specified parameter can be considered only in a complex assessment of efficiency of technologies for repairing buildings and other structures

It is established that among the parameters of external factors that can influence the complex evaluation of the efficiency of building technology, unfavourable production conditions arising from the fault of the contractor should not be included. These conditions are insufficient illumination of the construction object, imperfect state of equipment and tools, low qualification and dishonesty of performers, the risk of theft on unguarded object of materials and equipment, and probability of damage of building production in case of accidents and natural disasters (fires, earthquakes, etc.).

Thus, the number of parameters of the internal and external factors chosen as criteria can change from one to twenty depending on goals that need to be reached when applying the technology. Therefore, a set of twenty possible local criteria can be considered complete, and from a smaller number of them - selective. 
A selective set of local criteria can be formed by the customer, contractor, designer or other representative of the investment complex (subject of evaluation), taking into account their interest in the use of certain criteria. As a result of the carried out research of the specified interest, the author formed special sets of local criteria for the customer, contractor and designer (Table 3 ).

Table 3. Interest of representatives of the investment complex in the use of local criteria in a complex assessment of the effectiveness of construction technologies

\begin{tabular}{|c|c|c|c|}
\hline \multirow{2}{*}{ Parameters of factors used as local criteria } & \multicolumn{3}{|c|}{$\begin{array}{l}\text { Representative of investment complex } \\
\quad \text { (subject of assessment) }\end{array}$} \\
\hline & customer & designer & contractor \\
\hline$\frac{\text { Parameters of internal factors }}{1 . \text { Wastelessness of technology }}$ & - & - & + \\
\hline 2. Dirt adherence of common air & + & - & + \\
\hline 3. Cost of works & + & + & + \\
\hline 4. Injury risk of technology & - & - & + \\
\hline 5. Labour input of process & - & - & + \\
\hline 6. Fire danger of the equipment & + & - & + \\
\hline 7. Transportability of the equipment & - & - & + \\
\hline 8. Durability of building products & + & + & + \\
\hline 9. Maintainability of building products & + & - & + \\
\hline 10. Aesthetics of building products & + & + & - \\
\hline $\begin{array}{l}\text { Parameters of external factors } \\
\text { 1. Possibility of identification of unaccounted } \\
\text { geological anomalies in construction zone }\end{array}$ & + & + & - \\
\hline $\begin{array}{l}\text { 2. Possibility of identifying unaccounted shortcomings } \\
\text { in the structure being repaired }\end{array}$ & + & + & + \\
\hline 3. Risk of interruptions in supply with materials & - & - & + \\
\hline 4. Risk of interruptions in power supply & - & - & + \\
\hline 5. Risk of windy weather & - & - & + \\
\hline 6. Risk of rainy weather & - & - & + \\
\hline 7. Risk of winter work conditions & - & - & + \\
\hline $\begin{array}{l}\text { 8. Risk of increasing the intensity of the building } \\
\text { products use }\end{array}$ & + & + & + \\
\hline $\begin{array}{l}\text { 9. Risk of deformation of supporting structures and } \\
\text { different type of the bases }\end{array}$ & + & - & + \\
\hline $\begin{array}{l}\text { 10. Risk of deterioration of heat and moisture } \\
\text { conditions of the building products exploitation }\end{array}$ & + & - & + \\
\hline
\end{tabular}


It is established that the representative of the contractor is interested in using the maximum possible number of local criteria, since the result of his activities is most dependent on the production conditions.

In addition, the designer is directly interested in using only six criteria. However, if the customer included special requirements for ensuring maintainability of building products, fire safety or wastelessness of technology and reducing the risk of atmospheric air pollution, the number of criteria in which the designer is interested in, respectively, increases.

To automate the process of complex assessment of the efficiency of building technologies, it is expedient to create a database with the values of parameters that can be used as local criteria [20].

\section{Conclusion}

The offered local criteria can find broad application for a complex assessment of the effectiveness of any construction technology, as well as their comparison with each other and the choice of the best, that is, the optimal technology.

It is possible to identify ways of improving building technologies at the lowest normalized values of these criteria.

Application of priority local criteria will allow to exclude expenses of time for their analysis and to avoid mistakes at their choice and also to provide possibility of automation of the choice of optimum building technologies.

\section{References}

1. E.K. Zavadskas, L. Ustinovichius, A. Stasiulionis, Journal of civil engineering and management, 9, 151-166 (2004)

2. K. Targiel, Operations research and decisions, 3, 55-62 (2012)

3. L. Ustinovichius, International journal of strategic property management, 8, 25-44 (2004)

4. L. Ustinovichius, G. Shevchenko, Computer modelling and new technologies, 12, 2937 (2008)

5. M.A. Velazquez, D. Claudio, A.R. Ravindran, International journal of operational research, 7, 413-428 (2010)

6. S.G. Osmanov, A.L. Zholobov, Inženernyj vestnik Dona, 1, 315 (2011)

7. E.A Zholobova, A.L. Zholobov, Nauchnoe obozrenie, 12, 83-85 (2013)

8. A. Kaklauskas, E.K. Zavadskas, S. Raslanas, Energy and Buildings, 37, 361-372 (2005)

9. R. Ginevicius, Business: theory and practice, 7, 3-13 (2006)

10. A. Frini, Guitouni, J. M. Martel, European journal of operational research, 220, 452460 (2012)

11. E.K. Zavadskas, F. Peldschus, Informatica, 16, 107-120 (2005)

12. H.K. Alfares, S.O. Duffuaa, IJITDM, 7, 769-781 (2008)

13. N. Simic, V. Vratonjic, I. Beric, Megatrend review, 8, 113-130 (2011)

14. V. Podvezko, Business: Theory and Practice, 7, 81-88 (2006)

15. E.A Zholobova, O.A. Zholobova, Inženernyj vestnik Dona, 1, 107 (2017)

16. B.G. Litvak, Expert technologies in management (Delo, Moscow, 2004) 
17. C.L. Hwang, K. Yoon, Multiple attribute decision making. Methods and applications (Springer-Verlag, Berlin, 1981)

18. S. Andersen, G. Harrison, M. Lau, E.E. Rutström, Journal of economic psychology, 41, 101-113 (2014)

19. R. Tamosiuniene, S. Sidlauskas, I. Trumpaite, Business: Theory and Practice, 7, 203$212(2006)$

20. E.K. Zavadskas, F. Peldschus, L. Ustinovichius, Informatica, 14, 259-272 (2003) 